\title{
Pelatihan Pembuatan Virtual Tour bagi Kelompok Sadar Wisata Desa Sidatapa, Kabupaten Buleleng, Bali
}

\author{
Ni Made Ary Widiastini, Made Aristia Prayudi, Putu Indah Rahmawati, Gede \\ Rasben Dantes
}

Universitas Pendidikan Ganesha

Korespondensi:ary.widiastini@gmail.com

\begin{abstract}
The presence of increasingly sophisticated information technology has implications for the emergence of various innovations and creativity, by utilizing the development of information technology. One that is growing rapidly during the pandemic is a virtual tour, as a substitute for a tour to a place directly, which is brought to a screen using either a laptop, PC or mobile phone. Sidatapa Village, as one of the tourist villages in Buleleng Regency, has recently developed tourism products, one of which is a tour to get to know the culture in the village, experiencing obstacles due to the social restrictions. Tourists cannot visit the village directly and get to know the culture in the ancient village. Seeing the trend of virtual tours that are well developed in Indonesia, in this community service program, tourism community group who act as tour guides are given virtual tour training. Sidatapa village is unique, namely as the village of Bali Aga and has an old house called Bale Tumpang Salu, as well as ancient cultural activities which are still preserved until now, has the potential to develop a virtual tour. In village mentoring activities, tourism awareness groups are given virtual tour training involving the role of the industry, namely the Trex Tour. Through training and mentoring provided by academics and industry, the tourism awareness group of Sidatapa Village was able to design and carry out virtual tours.
\end{abstract}

Keywords: training, virtual tour, sidatapa village

\begin{abstract}
Abstrak
Kehadiran teknologi informasi yang semakin canggih berimplikasi pada munculnya berbagai inovasi dan kreativitas, dengan memanfaatkan perkembangan dari teknologi informasi tersebut. Salah satu yang sedang berkembang pesat pada masa pandemik adalah virtual tour sebagai pengganti perjalanan wisata ke suatu tempat secara langsung, yang dibawa ke dalam sebuah layar baik menggunakan device berupa laptop, PC, maupun mobile phone. Desa Sidatapa sebagai salah satu desa wisata di Kabupaten Buleleng yang baru saja mengembangkan produk wisata, salah satunya beriwisata mengenal budaya di desa tersebut, mengalami hambatan yang disebabkan oleh pembatasan sosial. Wisatawan tidak dapat berkunjung langsung ke desa tersebut dan mengenal budaya di desa tua tersebut. Melihat tren virtual tour yang berkembang baik di Indonesia maka pada program pengabdian kepada masyarakat ini, kelompok desa wisata yang berperan sebagai pemandu wisata diberikan pelatihan virtual tour. Desa Sidatapa memiliki keunikan, yakni sebagai desa Bali Aga, memiliki rumah tua yang disebut Bale Tumpang Salu, serta aktivitas budaya kuno yang hingga saat ini masih dipertahankan berpotensi untuk mengembangkan virtual tour. Pada kegiatan pendampingan desa, kelompok sadar wisata diberikan pelatihan virtual tour dengan melibatkan peran industri, yakni Trex Tour. Melalui
\end{abstract}


pelatihan dan pendampingan yang diberikan oleh pihak akademisi dan industri, kelompok sadar wisata Desa Sidatapa mampu merancang dan melaksanakan virtual tour.

Kata kunci: pelatihan, tur virtual, desa sidatapa

\section{Pendahuluan}

Desa Sidatapa sebagai salah satu dari lima desa tua atau Bali Aga di wilayah Kabupaten Buleleng Tengah secara konsisten mengembangkan dirinya sebagai desa wisata. Hal tersebut diapresiasi oleh pemerintah kabupaten dengan mengeluarkan penetapan desa tersebut sebagai desa wisata melalui Keputusan Bupati Buleleng Nomor 430/405/ HK/2017. Dalam pengembangannya, nilai serta norma desa yang ada tetap dilestarikan dan diadopsi sebagai pondasi dalam setiap kegiatan wisata yang dikembangkan di desa tersebut $^{1}$. Hal tersebut sejalan dengan imbauan ${ }^{2}$, yakni di dalam pengembangan desa wisata, diharapkan kegiatan wisata dan produk wisata yang dikembangkan mampu mempertahankan sakralisasi yang diusung oleh masyarakat desa.

Pariwisata pedesaan ${ }^{3}$ merupakan sebuah bentuk adanya integrasi di antara komponen pariwisata yang diwujudkan dalam suatu struktur kehidupan masyarakat yang memiliki tata cara dan tradisi tertentu. Oleh karena itu, dalam pengembangannya dibutuhkan pendekatan ${ }^{4}$ yang mungkin berbeda antara satu desa dan desa lainnya meski memiliki kesamaan potensi. Desa Sidatapa yang sedang secara serius mengembangkan dirinya sebagai desa wisata Bali Aga, dalam memperkenalkan dirinya sebagai tempat tujuan wisata, senantiasa masih mempertahankan tradisinya. Hal tersebut bertujuan untuk memberikan pemahaman kepada wisatawan yang berkunjung untuk mengetahui nilai dan norma yang berlaku di desa tersebut. Namun, kehadiran pandemi Covid-19 yang membuat pariwisata lesu, termasuk desa wisata, mengarahkan pelaku pariwisata harus lebih kreatif. Salah satu kegiatan yang dapat dilakukan adalah mempromosikan Desa Sidatapa sebagai tempat tujuan wisata yang unik secara virtual, menarik, dan mampu menghasilkan pendapatan dalam bentuk donasi.

Pada kondisi pandemi, virtual tour ${ }^{5},{ }^{6}$ dapat dimanfaatkan sebagai media promosi suatu daerah tujuan wisata. Virtual tour juga dikenal sebagai panoramic tour, yang merupakan sebuah kegiatan simulasi suatu tempat yang dituju secara riil di layar. Dalam penayangannya, pihak pelaksana kegiatan virtual tour disarankan menggunakan perangkat berupa laptop atau PC untuk memudahkan penampilan gambar $360^{\circ}$, gambar-

1 I. N. Murtana, N. D. Purnamwati, E. Soemaryatmi, and T. Harpawati, Tradisi Wisata Desa Sembiran Buleleng Bali. Surakarta, Jawa Tengah: ISI Press, 2018.

2 I. M. Bandem, "Peranan Seni dan Budaya Sebagai Komoditas Dalam Pengembangan Industri Pariwisata.” Universitas Udayana, 1998.

3 N. S. Arida and K. Pujani, "Kajian Penyusunan Kriteria -Kriteria Desa Wisata Sebagai Instrumen Dasar Pengembangan Desa Wisata," J. Anal. Pariwisata, vol. 17, no. 1, 2019.

4 N. Regmi, "Rural Tourism in Nepal: Development and Sustainability (A Case Study of Parbat District, Nepal),” CENTRIA UNIVERSITY OF APPLIED SCIENCES, 2016.

5 A. Yuliana and E. Lisdianto, "Aplikasi Virtual Tour sebagai Media Promosi Objek Wisata di Stone Garden Kab. Bandung Barat,” Kopertip, vol. 1, no. 1, pp. 19-24, 2017.

6 D. G. Thomas, S. R. U. A. Sompie, and B. A. Sugiarso, "Virtual Tour sebagai Media Promosi Interaktif Penginapan di Kepulauan Bunaken,” J. Tek. Inform., vol. 13, no. 1, 2018. 
gambar yang sudah disiapkan dalam hyperlink, video, dan lokasi yang dapat dicari melalui aplikasi Google Map. Virtual tour $360^{\circ}$ menggunakan basis web dan mampu menjadi solusi promosi suatu daerah tujuan wisata secara interaktif. Dalam hal ini dijelaskan bahwa ${ }^{7}$ virtual tour $360^{\circ}$ yang diterapkan dengan melakukan kombinasi pada layanan geolocation dengan tujuan pemetaan lokasi memiliki potensi untuk mewujudkan kegiatan promosi yang inovatif, kreatif, dan komunikatif, yang mampu menjangkau pasar secara luas dengan biaya yang relatif murah.

Desa Sidatapa ${ }^{8}$ merupakan desa dengan tradisi dan budaya yang kuat dalam mempertahankan kebudayaannya dari pengaruh luar, terlebih lagi jika berhubungan dengan adat istiadat dan upacara keagamaan. Dalam praktiknya, kebudayaan yang kuat dan unik justru dijadikan daya tarik oleh masyarakat setempat untuk menghadirkan wisatawan ke Desa Sidatapa. Ada cerita yang menarik di balik kebudayaan Desa Sidatapa yang tampak, baik rumah adatnya, ritualnya, maupun pertanian bambunya yang dapat diceritakan kepada wisatawan sehingga menjadi alasan maknawi bagi mereka untuk berkunjung ke desa tersebut. Selain itu, Desa Sidatapa berada di wilayah kompleks desa tua. Oleh karena itu, paket wisata terintegrasi pun sudah dikembangkan ${ }^{9}$ dengan melibatkan potensi lima desa, yakni Desa Sidatapa, Desa Cempaga, Desa Tigawasa, Desa Pedawa, dan Desa Banyuseri. Namun, dengan dimilikinya keunikan yang berbeda-beda di masing-masing desa tersebut, setiap desa juga mampu mengembangkan paketnya sendiri, termasuk Desa Sidatapa yang memiliki keunggulan Bale Tumpang Salu dan cerita dari bangunan tersebut.

Potensi budaya yang unik yang dimiliki oleh Desa Sidatapa merupakan peluang bagi kelompok sadar wisata di desa tersebut untuk mengembangkan virtual tour dengan memberikan pendampingan pada penyusunan informasi yang akan disampaikan oleh masyarakat selaku pemandu wisata secara virtual. Memahami bahwa pemandu wisata lokal telah memiliki kemampuan untuk bercerita serta mengetahui potensi budaya yang ada di desa untuk dikemas menjadi virtual tour, pendekatan nondirektif diimplementasikan pada program pengabdian ini. Pendekatan nondirektif (partisipatif) ${ }^{10}$ dilakukan dengan berlandaskan pada asumsi bahwa masyarakat tahu apa yang sebenarnya mereka butuhkan dan apa yang baik untuk mereka. Pada pendekatan ini, community worker pemeran utama dalam perubahan masyarakat adalah masyarakat itu sendiri. Community worker lebih bersifat menggali dan mengembangkan potensi masyarakat. Masyarakat diberikan kesempatan untuk membuat analisis dan mengambil keputusan yang berguna bagi mereka sendiri untuk tujuan yang mereka inginkan. Dalam kondisi pandemi ini, virtual tour dapat dijadikan sebagai media untuk memasarkan suatu daerah tujuan wisata dengan narasi dan gambar yang menarik dengan harapan wisatawan akan datang langsung ke destinasi yang dipromosikan setelah masa pascapandemi.

7 D. D. Prasetya, "Aplikasi Virtual Tour Berbasis Web sebagai Media Promosi Wisata," in Seminar on Electrical, Informatics and Its Education, 2011, no. October 2011, pp. A2-58-A2-62.

8 I. W. Gata, "Filosifis Sampradaya dalam Kehidupan Sosial Masyarakat Hindu di Bali (Studi Kasus di Desa Sidatapa, Kabupaten Buleleng)," Genta Hredaya, vol. 2, no. 1, pp. 24-36, 2018.

9 N. Diah Andini, A. A. N. Anom Kumbara, and I. B. G. Pujaastawa, "Peran Serta Elit Desa dalam Pengembangan Pariwisata di Desa Cempaga Kecamatan Banjar Kabupaten Buleleng Bali," HUMANIS, vol. 22, no. 1, pp. 87-95, 2018.

10 I. R. Adi, Intervensi Komunitas dan Pengembangan Masyarakat Sebagai Upaya Pemberdayaan Masyarakat. Jakarta: PT Raja Grafindo Persada, 2012. 


\section{Analisis Situasi}

Berdasarkan analisis situasi Desa Sidatapa, diketahui desa tersebut memiliki potensi budaya yang menarik dan sedang tekun mengembangkan pariwisata di daerahnya sejak tahun 2018. Namun, dengan kondisi pandemi yang bersifat global dan juga berimplikasi pada pengembangan desa tersebut, masyarakat masih mengharapkan kegiatan promosi desa sebagai tempat wisata yang unik kepada wisatawan, baik domestik maupun mancanegara. Oleh sebab itu, pada kesempatan ini, pelatihan pembuatan virtual tour diberikan sebagai solusi agar kelompok sadar wisata di Desa Sidatapa tetap mampu melakukan kegiatan promosi yang efektif dan sesuai dengan tren yang berlaku pada masa pandemi. Berdasarkan kondisi empiris yang telah disebutkan, permasalahan pokok yang menjadi prioritas utama yang hendak diurai melalui program ini adalah:

1. belum dipahaminya virtual tour yang menjadi produk wisata unggulan pada masa pandemi;

2. belum dipahaminya platform yang dapat digunakan untuk menjual virtual tour;

3. belum dipahaminya aplikasi yang digunakan untuk membuat virtual tour;

4. belum dipahaminya cara membuat paket wisata yang menarik untuk dijual kepada wisatawan secara virtual.

\section{Tujuan dan Manfaat Kegiatan}

Pelaksanaan kegiatan pengabdian "Pelatihan Pembuatan Virtual Tour bagi Kelompok Sadar Wisata Desa Sidatapa, Kabupaten Buleleng, Bali” memiliki tujuan sebagai berikut.

1. Memberikan pemahaman virtual tour yang menjadi produk wisata unggulan pada masa pandemi.

2. Meningkatkan kemampuan Pokdarwis untuk dapat digunakan untuk menjual virtual tour.

3. Meningkatkan kemampuan Pokdarwis untuk menggunakan yang dibutuhkan dalam pembuatan virtual tour.

4. Mampunya Pokdarwis membuat paket wisata yang menarik untuk dijual kepada wisatawan secara virtual.

Manfaat yang dapat diterima oleh masyarakat atas program pengabdian yang dilaksanakan pada Desa Sidatapa, Kabupaten Buleleng dapat dipaparkan sebagai berikut.

1. Bagi Mitra Kegiatan -> Kelompok Sadar Wisata My Darling mendapat pengetahuan dalam memanfaatkan platform Zoom dan aplikasi Google Map untuk membuat paket wisata yang menarik dalam bentuk virtual tour.

2. Bagi industri $\rightarrow$ Biro perjalanan wisata dapat melakukan kerjasama penjualan paket wisata virtual yang dimiliki oleh Pokdarwis My Darling Desa Sidatapa, khususnya tentang tradisi unik yang dimiliki oleh desa Bali Aga di Kabupaten Buleleng.

\section{Pendekatan Pelaksanaan Program}

Virtual tour merupakan hal yang baru bagi pariwisata di Buleleng, tetapi menjadi solusi global saat ini, termasuk bagi Desa Wisata Sidatapa, dan membuat Kelompok Sadar Wisata di desa tersebut memiliki keinginan yang kuat untuk mengembangkan tur secara virtual. Selama ini, mereka menjual tur kepada wisatawan, baik domestik maupun 
mancanegara, secara konvensional. Namun, penyebaran virus Covid-19 menyebabkan penjualan tur secara konvensional tidak dapat dilaksanakan. Menerima pendampingan dari tim PPDM Universitas Pendidikan Ganesha, kelompok masyarakat sadar wisata My Darling, Desa Sidatapa, mengharapkan pendampingan terkait virtual tour hingga mampu melakukan penjualan. Karena kondisi masyarakat yang masih awam terhadap hal-hal teknis terkait virtual tour, di antaranya platform Zoom dan Google Map, maka metode yang diberikan adalah pelatihan dan pendampingan.

Memahami masyarakat yang telah mengetahui potensi (sumber-sumber daya budaya) yang tersedia di desanya serta telah memiliki kemampuan untuk bercerita, baik menggunakan bahasa asing maupun bahasa Indonesia, maka pendekatan yang digunakan adalah pendekatan nondirektif. Pendekatan nondirektif memberikan peran yang lebih banyak kepada masyarakat, sementara tim pelaksana pengabdian berperan mendampingi kelompok sadar wisata My Darling dalam menyusun informasi, menggunakan teknologi yang telah tersedia di internet, serta mendampingi pada saat penjualan apabila membutuhkan bantuan sebagai host atau moderator.

Praktiknya, pelatihan dan pendampingan pembuatan virtual tour bagi kelompok sadar wisata Desa Sidatapa juga melibatkan pihak industri, yakni Trex Tour Academy. Pelibatan ini dilakukan dengan tujuan memberikan market linkage. Setelah pelatihan tour, mereka dapat bekerja sama dengan industri dalam berbagai bentuk untuk melakukan penjualan secara berkelanjutan. Praktiknya, peserta yang mau mengikuti pelatihan virtual tour diberikan pelatihan pendampingan dalam beberapa tahap, yakni pengenalan Zoom, pengenalan Google Map, pengenalan virtual tour, memahami aturan dalam virtual tour, menyusun paket wisata, dan menjual paket wisata secara virtual kepada wisatawan.

\section{Pelaksanaan Program}

\section{Penyediaan Panduan Penggunaan Platform dan Aplikasi Virtual}

Pada pelatihan pembuatan virtual tour bagi kelompok sadar wisata Desa Sidatapa, platform yang dipilih adalah Zoom. Dalam hal ini, masyarakat lebih mudah menggunakan Zoom, terutama pada saat ingin membagikan gambar-gambar. Kemudahan yang diberikan pada platform ini menjadi alasan tim pendamping desa wisata memberikan pelatihan penggunakan platform Zoom sebelum memulai pelatihan virtual tour. Selain itu, peserta pelatihan juga diberikan cara untuk mencari lokasi yang ingin diceritakan dengan menggunakan aplikasi Google Map.

\section{a). Panduan Penggunaan Platform Zoom}

Virtual tour mampu memberi pengalaman kepada peserta agar merasakan sensasi berada pada suatu tempat yang ditampilkan di layar monitor ${ }^{11}$. Virtual tour yang diberikan kepada kelompok sadar wisata My Darling Desa Sidatapa merupakan aktivitas wisata baru bagi mereka. Oleh sebab itu, dalam praktiknya, pengenalan platform dan aplikasi yang digunakan dalam kegiatan virtual tour menjadi wajib untuk diberikan dengan cara yang mudah untuk dimengerti oleh kelompok masyarakat tersebut. Memahami kondisi tersebut, maka panduan-panduan sederhana yang dibutuhkan menjadi kegiatan

11 G. N. M. Nata, "Aplikasi Virtual tour Guide sebagai Promosi Pariwisata Bali," J. Sist. dan Inform., vol. 11, no. 2, pp. 73-79, 2017. 
awal yang dilakukan oleh tim pelaksana pengabdian kepada masyarakat, dengan tujuan masyarakat sasaran mampu memahami dan menerapkan panduan yang diberikan. Pada pelatihan ini, platform Zoom dipilih sebagai platform yang digunakan dalam pelatihan virtual tour, dengan pertimbangan kemudahan penggunaan bagi masyarakat umum. Berikut panduan penggunaan platform Zoom yang diberikan kepada kelompok sadar wisata di Desa Sidatapa.

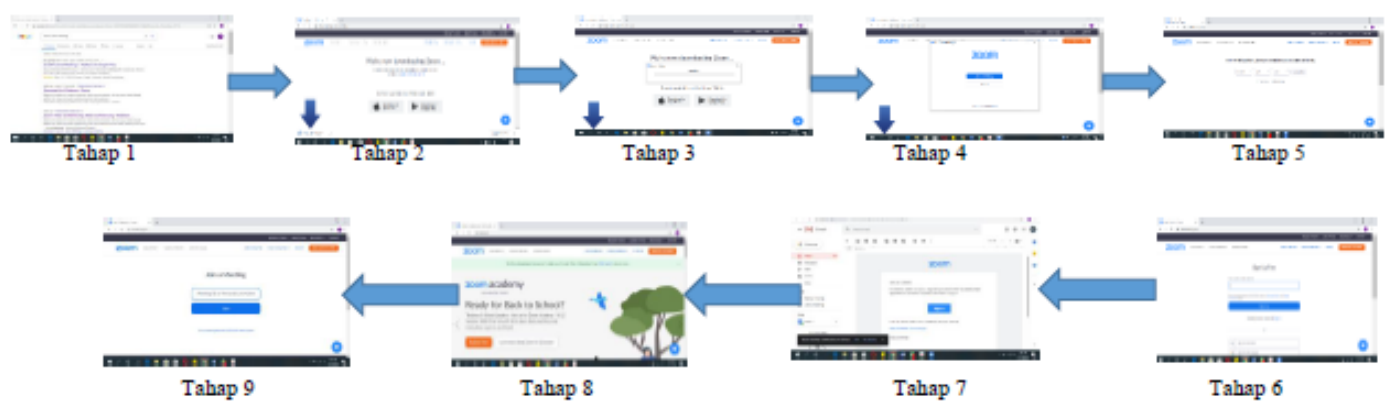

Gambar 1. Tahap Instal Zoom pada Windows (Sumber: Kreasi Tim PPDM Undiksha, 2020)

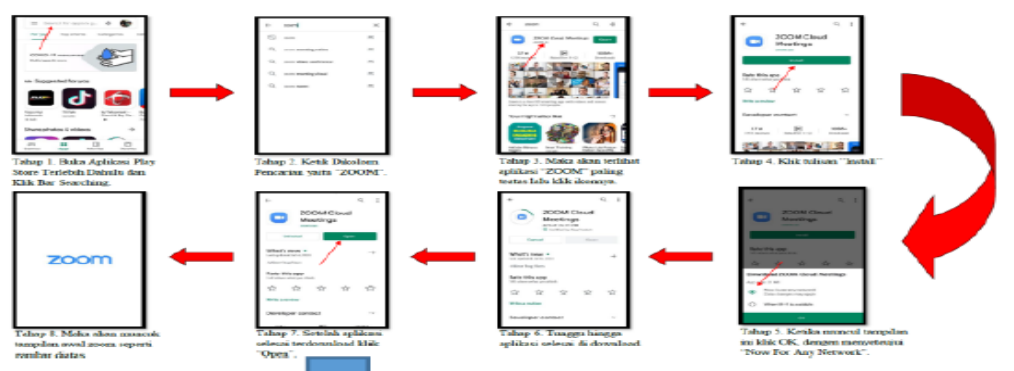

\section{LANJUTAN}
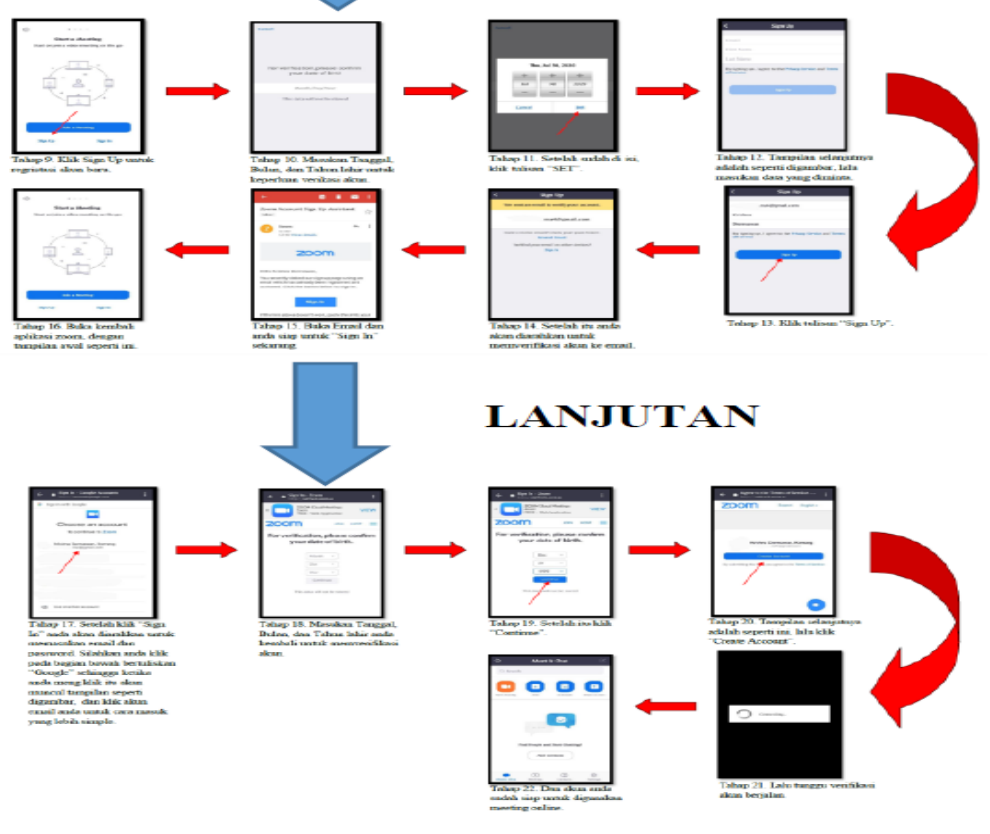

Gambar 2. Tahap Instal Zoom pada Android (Sumber: Kreasi Tim PPDM Undiksha, 2020) 
Gambar 1 merupakan tahapan untuk menginstal platform Zoom pada windows, baik pada perangkat berupa laptop maupun PC. Pada tahap pertama, peserta yang mengikuti pelatihan virtual tour diminta untuk membuka Zoom melalui Google dan selanjutnya membuka zoom.us. Kemudian, dilanjutkan untuk melakukan registrasi yang bertautan dengan e-mail. Bagi peserta yang belum memiliki e-mail, tim pendamping memberikan bantuan cara membuat email. Setelah peserta bisa melakukan registrasi, mereka diberikan pelatihan dengan memanfaatkan platform Zoom yang telah terinstal pada perangkat elektronik mereka. Selain diberikan pelatihan dengan menggunakan perangkat berupa laptop maupun PC, peserta juga diberikan cara menginstal platform Zoom menggunakan sistem android yang ada di telepon genggam.

Zoom sebagaimana pandangan ${ }^{12}$ dalam penelitiannya terhadap sejumlah perawat dijelaskan bahwa meskipun beberapa kendala dihadapi saat melakukan tatap muka melalui layar, platform Zoom dianggap baik dari sisi efektivitas biaya, fitur, dan keamanan. Penggunaan platform Zoom pada telepon genggam memberikan kemudahan bagi peserta

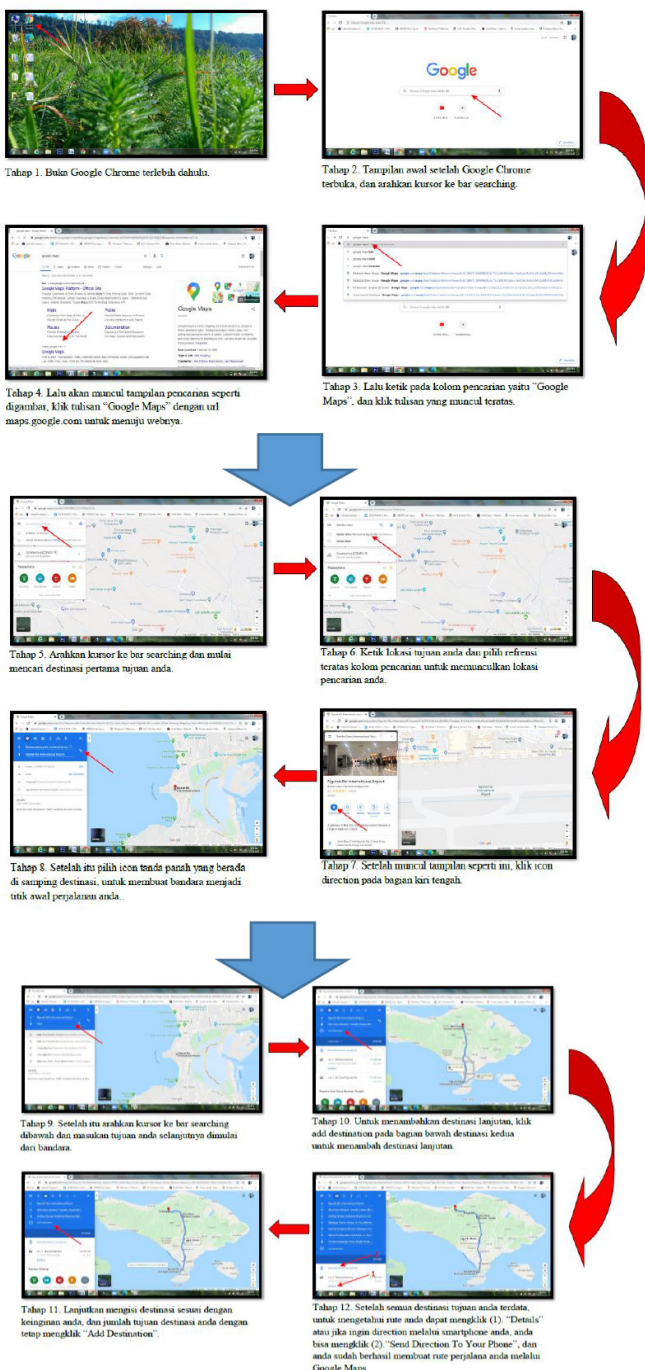

Gambar 3. Pembuatan Rute Virtual Tour pada Google Map (Sumber: Kreasi Tim PPDM Undiksha, 2020) untuk mengikuti pelatihan virtual tour pada tahap pengenalan. Namun, untuk tahap pelatihan lanjutan, peserta diwajibkan menggunakan laptop atau PC dengan tujuan memahami penggunaan aplikasi yang dibutuhkan pada saat membuat paket tur, rute, serta menampilkan gambar-gambar yang dibutuhkan.

\section{b). Panduan Penggunaan Aplikasi Google Map untuk Membuat Rute Perjalanan Wisata}

Pembuatan paket tur untuk kegiatan virtual tour secara konsep sama dengan membuat paket wisata konvensional. Rute yang dipilih pun sama seperti pada umumnya membuat rute konvensional. Namun, pada virtual tour, rute ditampilkan di layar dan setiap destinasi yang dituju ditunjukkan secara virtual, baik menggunakan gambar yang telah

12 M. M. Archibald, R. C. Ambagtsheer, M. G. Casey, and M. Lawless, "Using Zoom Videoconferencing for Qualitative Data Collection: Perceptions and Experiences of Researchers and Participants," Int. J. Qual. Methods, vol. 18, pp. 1-18, 2019. 
dimiliki maupun street view $360^{\circ}$ yang diperoleh di Google Map.

Aplikasi Google Map sangat membantu pembuatan dan penjualan virtual tour untuk menjadi menarik dan terkesan hidup karena menghadirkan destinasi yang dituju, berupa gambar $360^{\circ}$, dan dapat digerakkan. Praktiknya, pihak penyusun paket wisata virtual dapat menampilkan lokasi yang dikehendaki dengan melakukan tag secara mandiri terlebih dahulu. Hal tersebut dapat menampilkan lokasi destinasi secara khusus. Satu hal yang harus diperhatikan adalah lokasi yang di-tag pada Google Map bersifat umum dan tentunya sudah mendapatkan izin dari pihak yang memiliki kewenangan untuk dipublikasikan. Teknologi peta, yakni Google $\mathrm{Map}^{13}$, merupakan sistem informasi lalu lintas berbasis web yang saat ini sudah banyak dimanfaatkan untuk berbagai keperluan, termasuk dalam dunia bisnis seperti saat ini, yakni tur virtual. Pada kondisi pasar yang sangat kompetitif, Google Maps mampu memainkan peran yang dibutuhkan dalam membuat peta berbasis web. Praktiknya, dalam mengoperasikan aplikasi dengan menggunakan Google Map, tentu koneksi internet menjadi hal penting yang harus diperhatikan.

\section{Pelatihan Penggunaan Aplikasi Virtual}

\section{a). Pemberian Contoh Virtual Tour dengan Platform Zoom}

Guna memahami peluang kegiatan wisata dalam bentuk virtual yang dapat dijadikan sebagai produk wisata dalam bentuk wisata virtual (virtual tour), tim pelaksana kegiatan juga memberikan pendampingan kepada masyarakat untuk mengetahui dan mempelajari cara penerapan virtual tour tersebut. Sebagaimana dijelaskan bahwa di dalam membangun e-tourism ${ }^{14}$, virtual tour adalah salah satu solusinya. Pesatnya perkembangan teknologi yang semakin canggih menuntut pelaku pariwisata harus mampu memunculkan berbagai inovasi, yakni menyajikan informasi tentang keunikan suatu tempat tujuan wisata secara virtual dengan menggunakan aplikasi yang berbayar maupun bisa diakses secara gratis di internet.

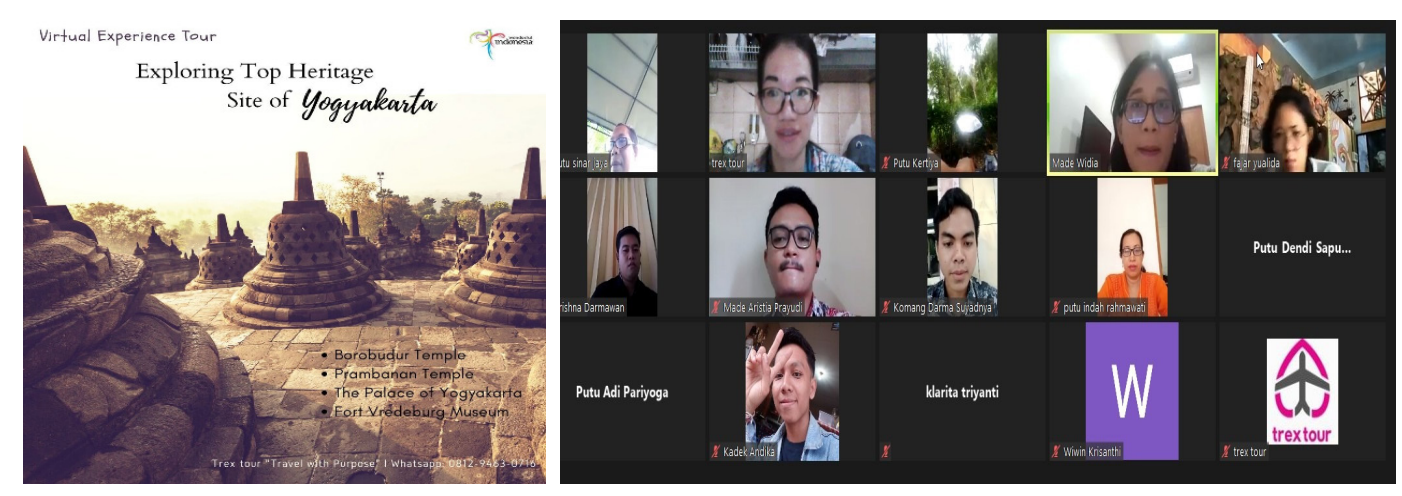

Gambar 4. Pengenalan Virtual Tour kepada Pokdarwis My Darling (Sumber: Kreasi Tim PPDM Undiksha, 2020)

13 Y.-J. Wu, Y. Wang, and D. Qian, "A Google-Map-Based Arterial Traffic Information System,” in IEEE Intelligent Transportation Systems Conference, 2007, pp. 968-973.

14 M. U. Kawulur, Y. D. Y. Rindengan, and X. B. N. Najoan, "Virtual tour e-Tourism Objek Wisata Alam di Kabupaten Biak Numfor,” J. Tek. Inform., vol. 13, no. 3, pp. 1-6, 2018. 
Pada kesempatan ini, tim pelaksana kegiatan melibatkan industri jasa wisata, yakni Trex Tour untuk memberikan pelatihan kepada Kelompok Sadar Wisata My Darling dalam pemberian pelatihan pembuatan Tour at Ancient Village of Sidatapa. Kegiatan pelatihan virtual tour tersebut diawali dengan mengenal tentang tur virtual, dengan tema "Exploring Top Heritage Site of Yogyakarta". Melalui pengenalan virtual tour dengan tema budaya, diharapkan Kelompok Sadar Wisata My Darling yang dibentuk dengan melibatkan berbagai unsur masyarakat Desa Sidatapa memahami jenis produk wisata yang sedang berkembang. Pada pelatihan ini hadir ketua kelompok sadar wisata, yakni Bapak Sinar dan tim kerjanya yang mulai memahami perkembangan digital dalam pariwisata, yang harus mampu dimanfaatkan juga oleh pengelola desa wisata.

\section{b) Pelatihan Virtual Tour dengan Aplikasi Google Map dan Platform Zoom}

Kehadiran teknologi informasi yang semakin canggih berimplikasi pada munculnya berbagai inovasi dan kreativitas, dengan memanfaatkan perkembangan dari teknologi informasi tersebut. Salah satu yang sedang berkembang pesat pada masa pandemik adalah virtual tour yang berfungsi sebagai pengganti perjalanan wisata ke suatu tempat secara langsung, yang dibawa ke dalam sebuah layar, baik menggunakan device berupa laptop, PC, maupun mobile phone. Virtual tour merupakan penyampaian informasi tentang suatu daerah dengan mengambil lokasi yang tersedia di Google Map. Tujuan dari virtual tour ini adalah untuk menyampaikan atau memperkenalkan lokasi yang dapat dikunjungi, yang ditampilkan secara visual dengan panorama 3600 sehingga peserta yang mengikuti virtual tour dapat mengetahui situasi sekitar. Satu hal yang penting dalam virtual ini, selain menyusun paket tur dan mencari gambar yang menarik, adalah penyaji tur atau guide yang memandu harus mampu memberikan narasi yang baik tentang suatu daerah yang dikunjungi secara virtual.

Pelatihan secara virtual dilakukan dalam dua tahap, yakni (1) penjelasan tentang cara membuat virtual tour dan aplikasi yang harus digunakan serta (2) role play. Pada tahap satu, peserta akan diberikan penjelasan tentang cara membuat virtual tour yang meliputi aplikasi yang digunakan, cara menyusun paket wisata, cara menjelasakan setiap destinasi, cara berkomunikasi dengan peserta tour dari memulai hingga mengakhiri, serta memahami kendala-kendala yang mungkin terjadi pada saat penjualan virtual tour. Pada tahap ini, peserta diberikan tugas untuk menyusun paket wisata dengan memanfaatkan potensi desa yang mereka miliki. Selanjutnya, pada tahap kedua akan dibahas paket yang telah dibuat dengan melakukan role play yang dilakukan oleh peserta dari kelompok sadar wisata Desa Sidatapa. Praktiknya, pelatihan ini melibatkan pihak yang membidangi program virtual tour, yakni Trex Tour. Sebagaimana dijelaskan bahwa teknologi informasi sebagai hal yang penting dalam membantu desa wisata untuk melakukan promosi tentang potensinya ${ }^{15},{ }^{16}$, maka dalam penerapannya, kolaborasi dengan pihak yang memiliki kompentensi di bidangnnya menjadi sangat penting.

15 D. Yuliandari, O. Gilang, and F. Prasetyo, "Rancang Bangun Sistem Informasi Pariwisata Kecamatan Muaragembong Berbasis Web," J. Sisfokom, vol. 6, no. 2, pp. 144-151, 2017.

16 A. Herawati, A. Purwaningsih, U. Atma, J. Yogyakarta, I. Yonathan, and D. Handharko, "Promoting Village Tourism through the Development of Information Systems," Rev. Integr. Bus. Econ. Res., vol. 7, no. 1, p. 221, 2018. 


\section{Refleksi Capaian Program}

\section{Pendampingan Pembuatan Virtual tour Mandiri}

Program pengabdian kepada masyarakat yang diberikan kepada Desa Bali Aga, Desa Sidatapa, Kabupaten Buleleng bertujuan untuk melatih mereka yang berada dalam komunitas pariwisata, yakni Pokdarwis Desa Sidatapa, agar memahami cara membuat topik virtual tour, menyusun narasi yang akan diinformasikan pada saat virtual tour berlangsung, serta mengoperasikan perangkat elektronik mereka secara mandiri saat menjual virtual tour. Desa Sidatapa yang dikelilingi oleh empat desa tua lainnya di Kabupaten Buleleng bagian tengah memiliki potensi untuk mengemas sumber daya budaya yang tersedia menjadi produk virtual tour berepisode. Melalui kerja sama dengan agen wisata, yakni Trex Tour yang berkompeten serta memiliki lisensi, diharapkan masyarakat mampu mengembangkan virtual tour-nya lebih baik dan mendatangkan income melalui penjualan virtual tour tentang desa tua, khususnya yang ada di Kabupaten Buleleng.

\section{a) Pendampingan Mengoperasionalkan Virtual Tour secara Mandiri}

Virtual tour dalam perkembangannya telah dilakukan oleh berbagai pihak, baik secara individu maupun menggunakan jasa biro perjalanan wisata, desa wisata, dan pemandu wisata. Dalam praktiknya, kegiatan virtual tour menekankan pada penggunaan perangkat teknologi, yakni laptop atau PC. Hal itu menjadi narasi yang menarik sehingga mampu menghasilkan cerita yang membuat audiens senang mendengarkannya. Audiens memiliki kemampuan mengakses lokasi serta menampilkan gambar yang sesuai dengan topik wisata virtual yang disajikan. Pada pelatihan kedua ini, masing-masing individu yang telah mendapatkan pelatihan dan pendampingan selama satu minggu akan diberikan kesempatan untuk role play. Pada kegiatan role play ini, peserta pelatihan akan mencoba membuat paket tur virtual dan menceritakan setiap lokasi yang dikunjungi secara virtual.

Pada kegiatan pelatihan ini, ada peserta yang mengikuti pelatihan di Universitas Pendidikan Ganesha, ada pula yang mengikuti dari rumahnya masing-masing. Pada masa pandemi ini, segala kegiatan dilakukan dengan fleksibel dan mengikuti protokol kesehatan yang berlaku, tetapi tujuan pelatihan tetap dapat tercapai. Dalam hal ini, peserta yang mengikuti pelatihan tahap dua diberi kesempatan untuk mendemonstrasikan virtual tour yang telah mereka siapkan. Kegiatan role play yang diikuti oleh tujuh peserta pelatihan berlangsung dengan baik. Peserta sudah mulai mampu menceritakan lokasi

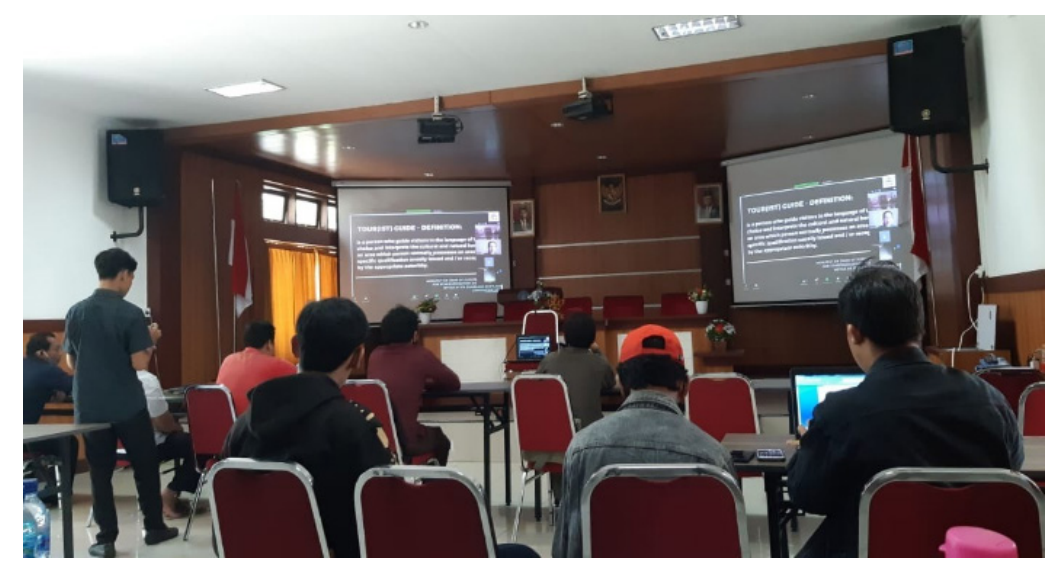

Gambar 5.

Pelatihan Virtual Tour di Salah Satu Ruang Pertemuan Universitas Pendidikan Ganesha (Sumber: Kreasi Tim PPDM Undiksha, 2020) 


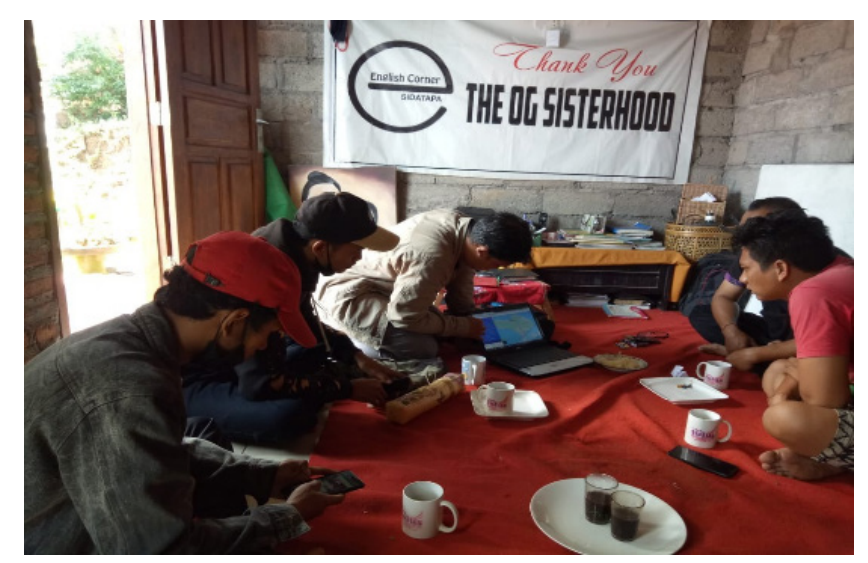

Gambar 6. Pendampingan Sebelum Penjualan Virtual Tour (Sumber: Kreasi Tim PPDM Undiksha, 2020)

wisata yang dikunjunginya secara virtual. Untuk tahap selanjutnya, kegiatan pelatihan akan dilakukan dengan mengundang audiens sebagai peserta virtual tour sebelum akhirnya mereka menjual paketnya kepada umum, baik konsumen domestik maupun luar.

Memahami kondisi masyarakat yang baru mengenal virtual tour tetapi memiliki semangat yang tinggi untuk bisa menjual paket wisata daerah mereka secara virtual, tim pendamping pun melaksanakan pendampingan secara intensif di Desa Sidatapa. Meminjam gagasan Ifa ${ }^{17}$, pendampingan memiliki peran penting, di antaranya, yakni sebagai fasilitator, pendidik, dan peran teknis bagi masyarakat yang didampingi. Dalam hal ini, pemahaman teknis terkait dengan virtual tour diperkuat dengan memberikan bimbingan teknis di rumah salah satu anggota kelompok sadar wisata. Melalui bimbingan teknis tersebut, sebagian dari peserta yang mengikuti pelatihan mampu meningkatkan pemahamannya, terutama hal-hal penting yang harus diketahui dalam penjualan virtual tour, di antaranya adalah cara membuka platform Zoom, aplikasi Google Map, gambar, dan narasi yang dibutuhkan.

\section{b) Pendampingan Penjualan Virtual Tour Desa Sidatapa oleh Pokdarwis My Darling}

Hilirisasi dari pelatihan yang diberikan kepada Kelompok Sadar Wisata My Darling, Desa Sidatapa, Kabupaten Buleleng, Bali adalah penjualan virtual tour secara umum. Tahap akhir pelatihan adalah menentukan tema unik agar memiliki nilai jual kepada wisatawan. Penyusunan tema melibatkan pihak yang akan menjadi narasumber, yakni kelompok sadar wisata Desa Sidatapa. Pada kesempatan ini, narasumber diberi pelatihan agar mampu bercerita secara menarik mengikuti gambar atau street view yang ditampilkan pada layar. Adapun tahap penjualan virtual tour adalah (1) menentukan tema, (2) membuat pamflet yang disebar melalui media sosial, (3) mendata peserta tur melalui Google Form, (4) gladi bersih, dan (5) virtual tour ditayangkan melalui platform yang telah ditentukan.

Berdasarkan gambar 7, penjualan melalui grup merupakan cara yang paling efektif. Dalam hal ini, target pasar juga menjadi pertimbangan dalam penjualan virtual tour secara online. Grup atau pihak yang diberi informasi adalah praktisi pariwisata dengan

17 A. N. Graha, "Pengembangan Masyarakat Pembangunan melalui Pendampingan Sosial dalam Konsep Pemberdayaan di Bidang Ekonomi," J. Ekon. Mod., vol. 5, no. 2, pp. 117-126, 2009. 


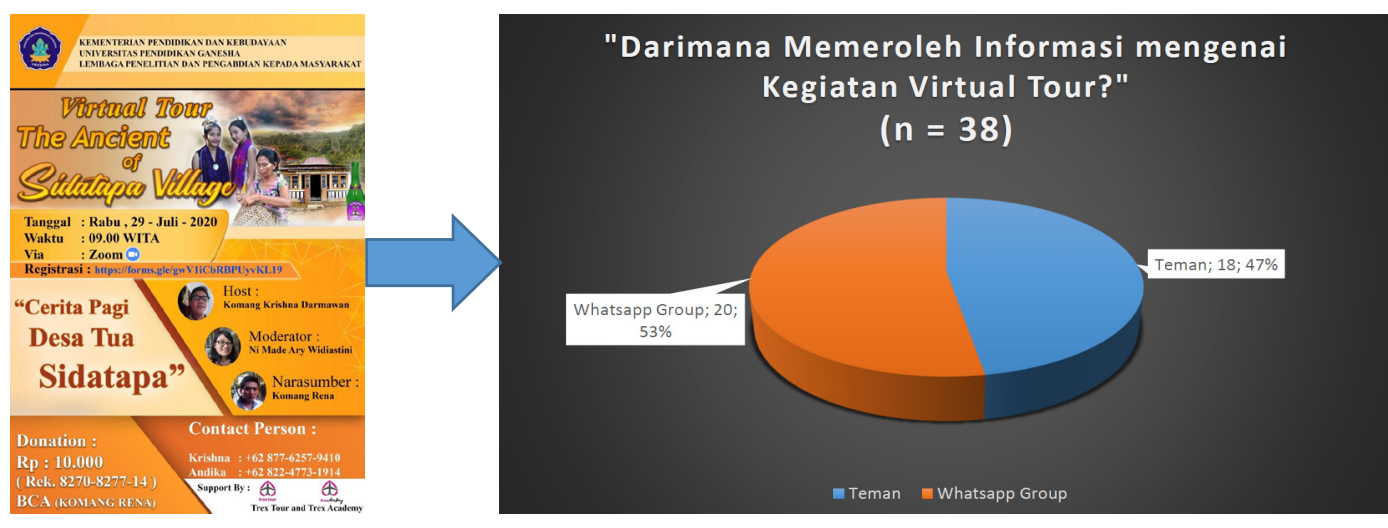

Gambar 7. Pemasaran Virtual Tour "The Ancient of Sidatapa Village" (Sumber: Kreasi Tim PPDM Undiksha, 2020)

berbagai bidang kerja dan akademisi, baik grup maupun personal. Berikut adalah data peserta yang membeli virtual tour yang diselenggarakan oleh kelompok sadar wisata Desa Sidatapa.

Melalui pengisian data yang dilakukan oleh peserta, diperoleh informasi bahwa sebagian besar peserta adalah praktisi pariwisata, yakni sebanyak $24 \%$, dan akademisi (dosen, mahasiswa, dan guru), yakni sebanyak 58\%. Hal ini menunjukkan bahwa target pasar, yaitu praktisi dan akademisi, telah tercapai, yakni $82 \%$. Berdasarkan pengamatan sebelumnya pada beberapa virtual tour yang dijual melalui berbagai media sosial, peminat virtual tour mayoritas adalah penekun pariwisata, akademisi, dan penulis.

Pendataan peserta secara online, yakni melalui Google Form, dibutuhkan untuk mengetahui ketercapaian dan kebutuhan pasar. Hal tersebut dapat digunakan sebagai pertimbangan dalam menyusun dan menjual virtual tour selanjutnya. Hal terpenting dalam penjualan virtual tour adalah ketersediaan sinyal yang baik, terutama pada host dan narasumber yang menjadi pihak penentu sukses tidaknya virtual tour. Sinyal yang merupakan kendala utama dalam penjualan menuntut pelaku virtual tour harus memastikan tersedianya sinyal yang baik pada saat kegiatan dilaksanakan. Selain itu, untuk mampu mengalihkan kebosanan atau emosi peserta akibat sinyal atau hal-hal teknis yang dapat membuat virtual tour tersebut mengalami masalah, terkadang dibutuhkan teman yang membantu narasumber seperti host atau moderator yang lokasinya berbeda. Diharapkan terjadi kolaborasi yang saling mendukung demi kesuksesan acara virtual tour yang dilaksanakan.

Kegiatan virtual tour yang menghadirkan anggota dari kelompok sadar wisata itu dimoderatori oleh ketua tim pendampingan desa wisata. Hal tersebut dilakukan mengingat narasumber pertama kalinya tampil sebagai guide secara virtual. Pada kesempatan tersebut, moderator dapat berperan membantu narasumber untuk mampu menceritakan tentang desa tua dengan baik serta merespons pertanyaan setiap peserta, baik yang masuk pada kolom chat di Zoom atau grup WhatsApp ${ }^{18}$. Pada konteks tersebut, moderator membantu mengarahkan narasumber untuk menjawab pertanyaanpertanyaan peserta dengan baik tanpa harus membaca pertanyaan secara langsung.

18 D. Jan, A. Roque, A. Leuski, J. Morie, and D. Traum, "A Virtual tour Guide for Virtual Worlds," Intelligent Virtual Agents, vol. 5773, no. September 2014. pp. 523-524, 2009. 


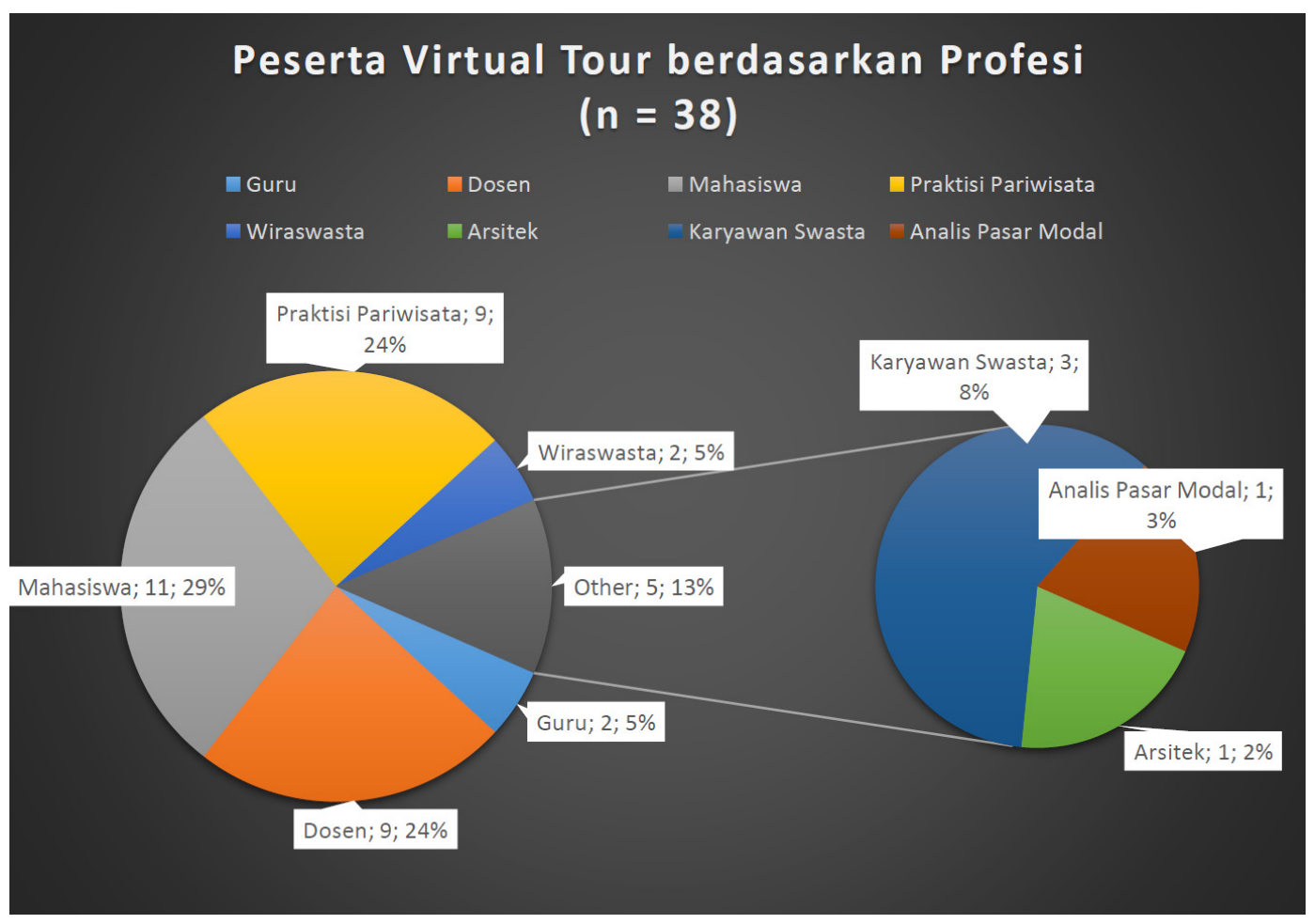

Gambar 8. Peserta Tur Berdasarkan Profesi

(Sumber: Olahan Data Google Form)

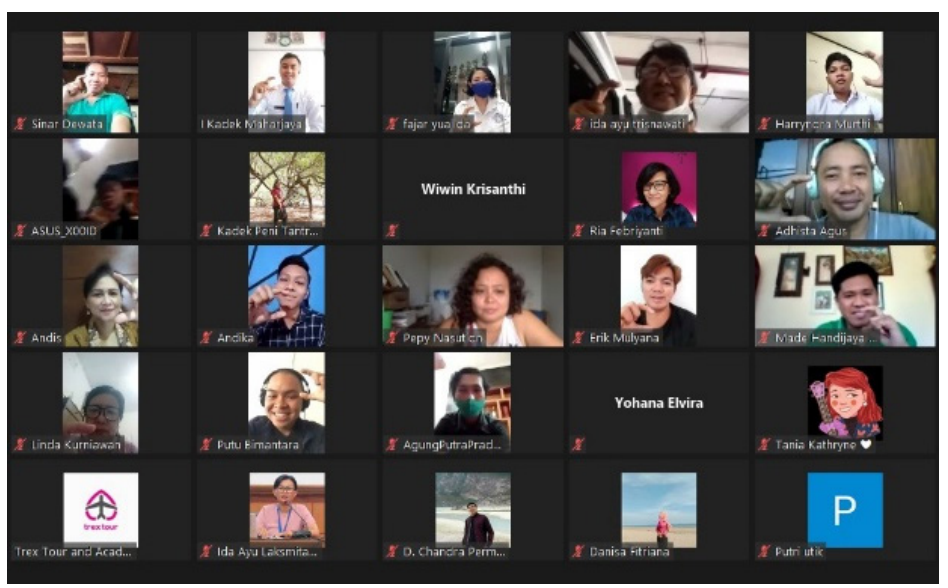

Gambar 9. Peserta Virtual Tour "Cerita Pagi Desa Tua Sidatapa" 29 Juli 2020

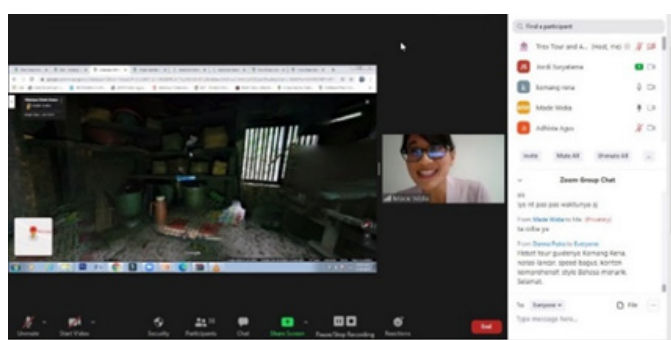

Gambar 10. Ketua Tim Pendamping Desa Wisata Memoderatori Narasumber dalam Virtual Tour "Cerita Pagi Desa Tua Sidatapa" 29 Juli 2020

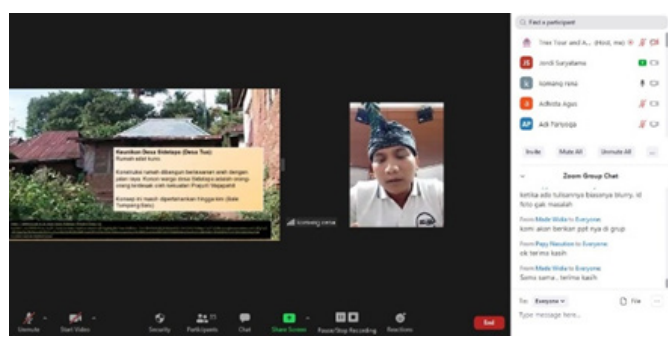

Gambar 11. Komang Rena Sebagai Narasumber dalam Virtual Tour "Cerita Pagi Desa Tua Sidatapa” 29 Juli 2020 
Beberapa virtual tour yang telah dilaksanakan oleh berbagai biro perjalanan wisata di Indonesia juga melakukan hal yang sama, dengan tujuan terjadi kelancaran informasi terkait dengan kegiatan wisata yang ditampilkan.

Sebagai pelaku pariwisata yang selama ini memandu wisata secara konvensional, Komang Rena, merupakan anggota kelompok sadar wisata yang sudah memiliki keterampilan baik dalam berkomunikasi. Hal yang harus diperhatikan dalam kegiatan virtual tour adalah tersedianya narasi yang baik dan valid. Terlebih lagi, virtual tour merupakan wisata virtual yang dijual dengan harga tertentu, yang kemudian menyebabkan hadirnya harapan konsumen untuk mendapatkan informasi sesuai dengan yang dijanjikan pada pamflet. Untuk itu, untuk dapat bercerita dengan baik dan sesuai dengan kaidah yang berlaku, tim pendamping desa wisata Universitas Pendidikan Ganesha telah membantu penyiapan artikel-artikel yang dibutuhkan dalam membangun narasi yang benar tentang Desa Sidatapa.

\section{Penutup}

Pelatihan pembuatan virtual tour yang diberikan oleh tim pendamping pengembangan desa wisata kepada kelompok sadar wisata My Darling Desa Sidatapa dilakukan melalui beberapa tahap kegiatan. Pengenalan platform serta aplikasi yang digunakan dalam pembuatan virtual tour merupakan kegiatan tahap awal yang diberikan kepada kelompok tersebut. Selanjutnya, kelompok tersebut diberi kesempatan untuk menonton virtual tour yang ditampilkan oleh Trex Tour, yang selanjutnya membantu tim pendamping dari Undiksha dalam memberikan pelatihan bersertifikat. Pada pelatihan terakhir, peserta diberi kesempatan untuk melakukan role play.

Tujuan pelatihan itu, yakni dimilikinya kemampuan pada kelompok sadar wisata My Darling Desa Sidatapa dalam membuat paket wisata yang menarik untuk dijual kepada wisatawan secara virtual, telah dilakukan setelah mereka mendapat pendampingan oleh tim akademisi dan praktisi. Paket pertama tentang cerita pagi di Desa Sidatapa telah mampu menghadirkan peserta tur virtual sebanyak 38 orang dengan sistem pembayaran berupa donasi. Memiliki keunikan sebagai desa tua atau Bali Aga dengan berbagai tradisi kunonya yang masih dipertahankan membuat tur virtual yang ditawarkan diminati oleh wisatawan dari kalangan akademisi, praktisi, wirausaha, arsitek, dan analis pasar modal.

Tur virtual sebagai aktivitas wisata yang ditampilkan melalui layar komputer, laptop, dan telepon genggam telah menjadi solusi bagi pelaku pariwisata, baik yang bergerak di bidang formal maupun nonformal. Diharapkan, kegiatan wisata virtual tersebut tidak hanya untuk kegiatan promosi, tetapi juga melatih pemandu wisata untuk mampu membangun narasi yang benar dan menarik. Dengan demikian, kemampuan mereka akan bermanfaat pada masa pascapandemi. Bahkan, wisata virtual yang menghadirkan masyarakat langsung sebagai narasumber dapat menjadi solusi untuk meraih pasar akademisi atau peneliti, yang tentunya membutuhkan informasi yang benar dan terbaru untuk menambah pengetahuan mereka terkait dengan budaya masyarakat.

\section{Ucapan Terima Kasih}

Terima kasih penulis sampaikan kepada Direktorat Riset dan Pengabdian Masyarakat 
atas direalisasikannya Program Pengembangan Desa Mitra sehingga kegiatan pengabdian kepada masyarakat dapat dilaksanakan dengan baik di Desa Sidatapa, Kabupaten Buleleng.

\section{Daftar Pustaka}

Adi, I.R. (2012). Intervensi Komunitas dan Pengembangan Masyarakat Sebagai Upaya Pemberdayaan Masyarakat. Jakarta: PT Raja Grafindo Persada.

Archibald, M.M. dkk. (2019). "Using Zoom Videoconferencing for Qualitative Data Collection: Perceptions and Experiences of Researchers and Participants" dalam Int. J. Qual. Methods, Vol. 18, hlm, 1-18.

Arida, N.S. dan K. Pujani. (2019). "Kajian Penyusunan Kriteria-Kriteria Desa Wisata Sebagai Instrumen Dasar Pengembangan Desa Wisata” dalam J. Anal. Pariwisata, Vol. 17, No. 1.

Bandem, I.M. (1998). "Peranan Seni dan Budaya Sebagai Komoditas dalam Pengembangan Industri Pariwisata". Bali: Universitas Udayana.

Diah Andini, N., A.A.N. Anom Kumbara, dan I.B.G. Pujaastawa. (2018). "Peran Serta Elit Desa dalam Pengembangan Pariwisata di Desa Cempaga Kecamatan Banjar Kabupaten Buleleng Bali” dalam HUMANIS, Vol. 22, No. 1, hlm. 87-95.

Gata, I.W. (2018). "Filosofis Sampradaya dalam Kehidupan Sosial Masyarakat Hindu di Bali (Studi Kasus di Desa Sidatapa, Kabupaten Buleleng)" dalam Genta Hredaya, Vol. 2, No. 1, hlm. 24-36.

Graha, A.N. (2009). "Pengembangan Masyarakat Pembangunan melalui Pendampingan Sosial dalam Konsep Pemberdayaan di Bidang Ekonomi” dalam J. Ekon. Mod., Vol. 5, No. 2, hlm. 117-126.

Herawati, A. dkk. (2018). "Promoting Village Tourism through the Development of Information Systems" dalam Rev. Integr. Bus. Econ. Res., Vol. 7, No. 1, hlm. 221.

Jan, D. dkk. (2009). "A Virtual tour Guide for Virtual Worlds" dalam Intelligent Virtual Agents, Vol. 5773, No. September 2014, hlm. 523-524.

Kawulur, M.U., Y.D.Y. Rindengan, dan X.B.N. Najoan. (2018). "Virtual tour e-Tourism Objek Wisata Alam di Kabupaten Biak Numfor" dalam J. Tek. Inform., Vol. 13, No. 3, hlm. 1-6.

Murtana, I.N. dkk. (2018). Tradisi Wisata Desa Sembiran Buleleng Bali. Surakarta: ISI Press.

Nata, G.N.M. (2017). "Aplikasi Virtual tour Guide sebagai Promosi Pariwisata Bali," J. Sist. dan Inform., Vol. 11, No. 2, hlm. 73-79.

Prasetya, D.D. (2011). "Aplikasi Virtual Tour Berbasis Web sebagai Media Promosi Wisata" dalam Seminar on Electrical, Informatics and Its Education, No. October 2011, hlm. A2-58-A2-62.

Regmi, N. (2016). "Rural Tourism in Nepal: Development and Sustainability (A Case Study of Parbat District, Nepal)". CENTRIA UNIVERSITY OF APPLIED SCIENCES.

Thomas, D.G., S.R.U.A. Sompie, dan B.A. Sugiarso. (2018). "Virtual Tour sebagai Media Promosi Interaktif Penginapan di Kepulauan Bunaken" dalam J. Tek. Inform., Vol. 13, No. 1.

Yuliana, A. dan E. Lisdianto E. (2017). “Aplikasi Virtual Tour sebagai Media Promosi 
Objek Wisata di Stone Garden Kab. Bandung Barat” dalam Kopertip, Vol. 1, No. 1, hlm. 19-24.

Yuliandari, D., O. Gilang, dan F. Prasetyo. (2017). "Rancang Bangun Sistem Informasi Pariwisata Kecamatan Muaragembong Berbasis Web” dalam J. Sisfokom, Vol. 6, No. 2, hlm. 144-151.

Y.J. Wu, Y. Wang, dan D. Qian. (2007). "A Google-Map-Based Arterial Traffic Information System" dalam IEEE Intelligent Transportation Systems Conference, hlm. 968-973. 